\title{
Zinc and cadmium as modulating factors of the morphophysiological responses of Alternanthera tenella Colla (Amaranthaceae) under in vitro conditions
}

\author{
E. CLAIRVIL* (D), J.P.R. MARTINS ${ }^{*, * *,+}$ (D), P.C.S. BRAGA* (D), S.W. MOREIRA* (D), \\ L.T. CONDE* (iD , R. CIPRIANO* (iD), A.R. FALQUETO* (iD), and A.B.P.L. GONTIJO* (iD \\ Department of Agrarian and Biological Sciences, Federal University of Espirito Santo, Litorâneo, \\ 29932-540 São Mateus, ES, Brazil \\ Institute of Dendrology, Polish Academy of Sciences, Parkowa 5, 62-035 Kórnik, Poland ${ }^{* *}$
}

\begin{abstract}
Zinc (Zn) plays an important role in the physiological processes in plants and may mitigate trace element stress. The aim was to evaluate the morphophysiological responses of Alternanthera tenella plants exposed to cadmium (Cd) and $\mathrm{Zn}$ under in vitro conditions. Segments of $A$. tenella were transferred to flasks containing medium supplemented with different combinations of $\mathrm{Cd}(0,75$, or $150 \mu \mathrm{M})$ and $\mathrm{Zn}(0,750$, or $1,500 \mu \mathrm{M})$ concentrations, totalizing nine treatments. We assessed the growth traits, anatomy, chlorophyll $a$ fluorescence by OJIPs, and tolerance index (TI). With exposure only to $\mathrm{Cd}$, the plants showed physiological disorders. Zn supplementation in the medium had a positive effect on the physiological performance of plants. At concentrations $\leq 750 \mu \mathrm{M}$, it can partially mitigate the deleterious effects of $\mathrm{Cd}$. Plants grown with $\mathrm{Cd}$ and $\mathrm{Zn}$ showed intermediate TI. The results proved the potential of $\mathrm{Zn}$ as a mitigator of $\mathrm{Cd}$-induced stress in plants.
\end{abstract}

Keywords: chlorophyll a fluorescence; electron transport flux; phytoremediation; plant tissue culture; trace element.

\section{Introduction}

Contamination and accumulation of industrial pollutants in the environment due to human activities can lead to potential damage to human health resulting from continuous exposure to their components (Jeong et al. 2020). The trace elements are among the elements that are pollutant and harmful to the ecosystem; they can

\section{Highlights}

- Both $\mathrm{Cd}$ and $\mathrm{Zn}$ alone and co-exposure can affect the morphophysiological traits of Alternanthera tenella

- Cd alone can induce physiological disorders in A. tenella

- $\mathrm{Zn}$ is a mitigator of $\mathrm{Cd}$-induced stress in $A$. tenella plants

\section{Received 18 July 2021}

Accepted 19 Novemver 2021

Published online 7 December 2021

${ }^{+}$Corresponding author

phone: +552731211696

e-mail: jprmartinss@yahoo.com.br

Abbreviations: $\mathrm{DI}_{0} / \mathrm{CSm}$ - dissipated energy flux per cross-section; $\mathrm{F}_{0}$ - initial fluorescence; $\mathrm{F}_{\mathrm{I}}$ - fluorescence intensity at $30 \mathrm{~ms}$; $\mathrm{F}_{\mathrm{J}}$ - fluorescence intensity at $2 \mathrm{~ms} ; \mathrm{F}_{\mathrm{K}}$ - fluorescence intensity at $0.3 \mathrm{~ms} ; \mathrm{F}_{\mathrm{m}}$ - maximal fluorescence intensity; $F_{\mathrm{P}}$ - fluorescence peak $\left(=\mathrm{F}_{300 \mathrm{~ms}}\right) ; \mathrm{F}_{\mathrm{t}}$ - fluorescence at time $\mathrm{t}$ after start of actinic illumination; $\mathrm{F}_{\mathrm{v}} / \mathrm{F}_{0}$ - ratio of the de-excitation rate constants for photochemical and nonphotochemical events; $\mathrm{K}_{\mathrm{P}}$ - photochemical de-excitation rate constant; $\mathrm{PI}_{\text {total }}$ - total performance index, which measures the performance up until the final electron acceptors of PSI; RC/CSm - total number of active reaction centers; $\mathrm{SFI}_{(\mathrm{ABS})}-\mathrm{PSII}_{\text {structure and }}$ functioning index; $\mathrm{V}_{\mathrm{I}}$ - relative variable fluorescence at $30 \mathrm{~ms}$ (step I); $\mathrm{V}_{\mathrm{J}}$ - relative variable fluorescence at $2 \mathrm{~ms}\left(\right.$ step J); $\mathrm{V}_{\mathrm{K}}-$ relative variable fluorescence at $0.3 \mathrm{~ms}($ step $\mathrm{K}) ; \mathrm{W}_{\mathrm{K}}$ - represents the damage to oxygen-evolving complex; $\mathrm{W}_{\mathrm{L}}$ - indicates disturbance in the thylakoid membranes, reducing the energetic connectivity between the PSII units; $\Delta \mathrm{V}_{\mathrm{IP}}$ - relative variable fluorescence amplitude of the increase from I to $\mathrm{P}=$ relative contribution of the increase from I to $\mathrm{P}$ to the increase in $\mathrm{OJIP} ; \varphi \mathrm{D}_{0}-$ quantum yield of energy dissipation (at $\mathrm{t}=0) ; \varphi \mathrm{E}_{0}$ - quantum yield of electron transport (at $\left.\mathrm{t}=0\right) ; \varphi \mathrm{P}_{0}$ - maximum quantum yield of primary photochemistry (at $\mathrm{t}=0) ; \varphi \mathrm{R}_{0}$ - quantum yield of reduction of end electron acceptors at the PSI acceptor side; $\psi \mathrm{R}_{0}-$ efficiency/probability by which electrons move from PSII to PSI acceptor side.

Acknowledgments: The authors acknowledge the scholarship granted by CNPq (National Council for Scientific and Technological Development), CAPES (Coordination for the Improvement of Higher Education Personnel), and FAPES (Espírito Santo Research Foundation). The authors also acknowledge Luiz Carlos de Almeida Rodrigues for technical assistance.

Conflict of interest: The authors declare that they have no conflict of interest. 
accumulate in the air, water, and soil, especially in mining areas, where their bioavailability can be high (Alloway 2013, Wang et al. 2017a, Logiewa et al. 2020).

Trace elements can have distinct effects on plants (Shahid et al. 2016, Xu et al. 2020). Some metals such as copper $(\mathrm{Cu})$, zinc $(\mathrm{Zn})$, iron $(\mathrm{Fe})$, cobalt $(\mathrm{Co})$, and manganese $(\mathrm{Mn})$ are considered essential and have a known function in the cellular metabolism of plants (Kirkby 2012, Lange et al. 2017). In contrast, others such as cadmium $(\mathrm{Cd})$, lead $(\mathrm{Pb})$, silver $(\mathrm{Ag})$, and mercury $(\mathrm{Hg})$ have no metabolic role in plants and can induce toxicity symptoms (Amari et al. 2017, Karri et al. 2018).

The presence of trace elements such as $\mathrm{Cd}$ at high concentrations in plants can limit growth, decrease pigment content, induce photosynthetic performance and anatomy disorders, cell damage is caused by increased reactive oxygen species (ROS). In addition, the plants may present visual symptoms of stress such as chlorosis or necrosis and even plant death (Ahmad et al. 2015, Amari et al. 2017). For some plant species, $\mathrm{Cd}$ can be toxic even in minimal amounts. It is often considered a contaminant affecting numerous physiological and biochemical processes (Amari et al. 2017, Samiei et al. 2020).

$\mathrm{Zn}$ is an important element for plants, as it regulates physiological and metabolic processes (cofactor of peroxidases, regulator of cell multiplication) (Kirkby 2012, Verma et al. 2016, Sturikova et al. 2018). Moreover, the $\mathrm{Zn}$ concentration influences the growth, development, and performance of the PSI and/or PSII in plants (MazaheriTirani and Dayani 2020). Zn can compete with other metals at absorption sites at high concentrations, reducing leaf area, inducing oxidative stress, chlorosis, or necrosis in plants, among other deleterious effects (Adhikari et al. 2016). Thus, the toxicity of metals in plants depends on their concentration.

Co-exposure to $\mathrm{Cd}$ and $\mathrm{Zn}$ in plants may enable $\mathrm{Cd}$ induced detoxification and proper functioning of cellular functions. Previous studies on co-exposure of these two metals $(\mathrm{Cd}$ and $\mathrm{Zn})$ in Alternanthera tenella and Cosmos bipinnatus plants have shown that $\mathrm{Zn}$ can suppress the Cd uptake, protecting plants against phytotoxic effects or contributing to detoxification of this metal by increasing the antioxidant system activity (Rodrigues et al. 2017, Du et al. 2020). From a more advanced perspective, this present study examined the level of $\mathrm{Cd}$-induced disorders in the photosynthetic apparatus (by chlorophyll $a$ fluorescence) in $A$. tenella plants and the role of $\mathrm{Zn}$ in mitigating the stress induced by this nonessential trace element.

Plants can develop morphophysiological mechanisms to survive and reproduce even with high concentrations of trace elements in their environment. The capacity of plants to uptake or accumulate pollutants in their biomass may allow their use for phytoremediation proposals (Carolin et al. 2017, Rodrigues et al. 2017). Some species of the Amaranthaceae family, such as A. tenella, have been identified for their ability to accumulate and stabilize contaminants present in soils degraded by mining or human activities (Pereira et al. 2016, Ayangbenro and Babalola 2017, Men et al. 2018).

The assessment of morphophysiological responses of plants under the effect of trace elements during their development and growth can be carried out under in vitro conditions. In vitro culture enables a careful study of physiological and anatomical processes of plants since it can isolate the effects of a trace element from the effects of other stresses (Martins et al. 2016, 2020, 2021; Rodrigues et al. 2017). Chlorophyll (Chl) $a$ fluorescence analysis in plants grown under stress may also be advantageous to evaluate photochemical changes in PSII and or PSI caused by trace elements in plants (Martins et al. 2020).

Considering the potential for bioaccumulation of the species A tenella pointed out by Rodrigues et al. (2017), further analysis of its physiological mechanisms can help understand Cd-tolerance strategies, including co-exposure to $\mathrm{Zn}$. Thus, the objective of this work was to evaluate the morphophysiological responses of $A$. tenella plants exposed to different concentrations of $\mathrm{Cd}$ and $\mathrm{Zn}$ under in vitro conditions. In addition, we assessed the potential of $\mathrm{Zn}$ for the mitigation of $\mathrm{Cd}$-induced stress.

\section{Materials and methods}

Plant material and exposure to $\mathrm{Cd}$ and $\mathrm{Zn}$ : Nodal segments $(2.5 \pm 0.5 \mathrm{~cm})$ obtained from $A$. tenella plants previously cultured in the MS medium (Murashige and Skoog 1962) without any plant growth regulator were used as explants (Rodrigues et al. 2017). This step was carried out with MS medium at full-strength $\left(440.0 \mathrm{mg} \mathrm{L}^{-1} \mathrm{CaCl}_{2}\right.$. $\mathrm{H}_{2} \mathrm{O} ; 1,900.0 \mathrm{mg} \mathrm{L}^{-1} \mathrm{KNO}_{3}, 370.0 \mathrm{mg} \mathrm{L}^{-1} \mathrm{MgSO}_{4} .7 \mathrm{H}_{2} \mathrm{O}$, $170.0 \mathrm{mg} \mathrm{L} \mathrm{KH}_{2} . \mathrm{PO}_{4}, 1,650.0 \mathrm{mg} \mathrm{L}{ }^{-1} \mathrm{NH}_{4} \mathrm{NO}_{3}, 22.3$ $\mathrm{mg} \mathrm{L}^{-1} \mathrm{MnSO}_{4} .4 \mathrm{H}_{2} \mathrm{O}, 6.2 \mathrm{mg} \mathrm{L}^{-1} \mathrm{H}_{3} \mathrm{BO}_{3}, 0.83 \mathrm{mg} \mathrm{L}^{-1} \mathrm{KI}$, $0.25 \mathrm{mg} \mathrm{L} \mathrm{Na}_{2} \mathrm{MoO}_{4} .2 \mathrm{H}_{2} \mathrm{O}, 8.6 \mathrm{mg} \mathrm{L}^{-1} \mathrm{ZnSO}_{4} .7 \mathrm{H}_{2} \mathrm{O}$, $0.025 \mathrm{mg} \mathrm{L}^{-1} \mathrm{CoCl}_{2} .6 \mathrm{H}_{2} \mathrm{O}, 0.025 \mathrm{mg} \mathrm{L}^{-1} \mathrm{CuSO}_{4} .5 \mathrm{H}_{2} \mathrm{O}$, $27.85 \mathrm{mg} \mathrm{L}^{-1} \mathrm{FeSO}_{4} .7 \mathrm{H}_{2} \mathrm{O}, 37.25 \mathrm{mg} \mathrm{L}^{-1} \mathrm{Na}_{2}$ EDTA, 0.5 $\mathrm{mg} \mathrm{L}^{-1}$ pyridoxine. $\mathrm{HCl}, 0.5 \mathrm{mg} \mathrm{L}^{-1}$ nicotinic acid, $0.5 \mathrm{mg} \mathrm{L}^{-1}$ thiamin. $\mathrm{HCl}, 2.0 \mathrm{mg} \mathrm{L}^{-1}$ glycine, $100 \mathrm{mg} \mathrm{L}^{-1}$ myo-inositol). The plant material (nodal segments) was subcultured for $45 \mathrm{~d}$ in $500-\mathrm{mL}$ glass flasks with $30 \mathrm{~mL}$ of modified (absence of $\mathrm{Zn}=0 \mu \mathrm{M}$ or $\mathrm{Zn}+0 \mu \mathrm{M} \mathrm{Cd}$ ) MS medium. After $45 \mathrm{~d}$, new nodal segments were collected from these plants and transferred to $500-\mathrm{mL}$ glass flasks containing $30 \mathrm{~mL}$ of modified MS medium, supplemented with $\mathrm{Zn}$ $(0,750$, or $1,500 \mu \mathrm{M})$. $\mathrm{Zn}$ treatments were combined with three concentrations of $\mathrm{Cd}(0,75$, or $150 \mu \mathrm{M})$, nine treatments in total. Cadmium nitrate $\left[\mathrm{Cd}\left(\mathrm{NO}_{3}\right)_{2} .4 \mathrm{H}_{2} \mathrm{O}\right]$ and zinc sulfate $\left[\mathrm{ZnSO}_{4} .7 \mathrm{H}_{2} \mathrm{O}\right]$ were used as sources of $\mathrm{Cd}$ and $\mathrm{Zn}$, respectively. The concentrations of $\mathrm{Cd}$ and $\mathrm{Zn}$ were chosen according to Rodrigues et al. (2017).

At all stages, the media were supplemented with $20 \mathrm{~g} \mathrm{~L}^{-1}$ sucrose and solidified with $6 \mathrm{~g} \mathrm{~L}^{-1}$ agar. The $\mathrm{pH}$ of all culture media was adjusted to 5.8 and autoclaved at $120^{\circ} \mathrm{C}$ for $20 \mathrm{~min}$. The plant material was kept in a growth room for $45 \mathrm{~d}$ (modified MS medium - absence of $\mathrm{Zn}$ ), then for $30 \mathrm{~d}$ (co-exposure to $\mathrm{Zn}-\mathrm{Cd}$ ) at $26 \pm 2{ }^{\circ} \mathrm{C}$, with a 16 -h photoperiod (08:00 to 00:00 h) under slim LED lamps (Blumenau $\left.{ }^{\circledR} 36 \mathrm{~W} / 6500 \mathrm{~K}\right)$, emitting $70 \mu \mathrm{mol}$ (photon) $\mathrm{m}^{-2} \mathrm{~s}^{-1}$ of PAR.

Plant growth and tolerance index (TI): After $30 \mathrm{~d}$ of culture (co-exposure to $\mathrm{Zn}-\mathrm{Cd}$ ), the $A$. tenella plants were washed in running water. The growth was analyzed in 25 plants per treatment, which were randomly divided into 
five different repetitions (replications). The quantification of total dry mass (DM) [mg per plant] (aerial part + roots) was performed with the aid of an analytical balance. The dry mass of $A$. tenella plants (aerial part and root) in each treatment was also used to calculate the TI according to the methodology proposed by Wilkins (1957) with modifications. The TI was determined as follows: $\mathrm{TI}=$ $\left[\left(\mathrm{DM}_{\text {treatment }}\right) /\left(\mathrm{DM}_{\text {control }}\right)\right] \times 100$, with varying $\mathrm{TI}$ values that can range from 0 [maximum sensitivity $=0 \%$ ] to 100 [maximum tolerance $=100 \%$ ]. $\mathrm{DM}_{\text {treatment }}=$ dry mass of plants grown in medium containing trace element(s). $\mathrm{DM}_{\text {control }}=$ overall mean of dry mass of plants in the control treatment $(0 \mu \mathrm{M} \mathrm{Cd}+0 \mu \mathrm{M} \mathrm{Zn})$.

Anatomical analyses: At the end of the experiment, the anatomy of the $A$. tenella plants was also analyzed. Five plants were randomly collected from each treatment and fixed in a FAA solution (formaldehyde, acetic acid, and $50 \%$ ethanol at a ratio of 0.5:0.5:9) (Johansen 1940). Cross- and paradermal sections of $A$. tenella were obtained as described by Martins et al. (2020). Anatomical analyses were performed on five different samples (repeats) per treatment. After mounting the slides, photomicrographs of the cross- and paradermal sections were obtained using an optical microscope (Bioval, L-2000A-Flur) coupled to a Leica EC3 digital camera (Wetzlar, Germany). Measurements of anatomical characteristics were performed using UTHSCSA-Imagetool ${ }^{\circledR}$ software calibrated with a microscopic ruler. The photomicrographs of the stem and leaves were obtained from two different cross-sections for each organ and the paradermal ones from four fields per sample (repeat). In stem sections, the number of vascular bundles and cross-area $\left[\mu \mathrm{m}^{2}\right]$ was measured. In leaf sections, the number of vessel elements, stomatal density $\left[\mathrm{mm}^{-2}\right]$, and stomata size $\left[\mu \mathrm{m}^{2}\right]$ was analyzed.

Assessment of Chl $\boldsymbol{a}$ fluorescence transient OJIP and JIP test: The assessments of Chl $a$ fluorescence transients of $A$. tenella plants exposed to different concentrations of $\mathrm{Cd}$ and $\mathrm{Zn}$ were carried out after $30 \mathrm{~d}$ of culture in 20 plants per treatment, between 8:00 and 10:00 $\mathrm{h}$ with the aid of a HandyPEA portable fluorometer (Hanstech, King's Lynn, Norfolk, UK). The measurements were performed on the second leaf fully expanded from the apex. The analyzed leaf area was previously dark-adapted using leaf clips $($ Hansatech $\AA$ ) for $30 \mathrm{~min}$. Based on the fluorescence intensities, we obtained the JIP test parameters, as well as the OJIP transients. The treatment without the addition of $\mathrm{Cd}$ and $\mathrm{Zn}(0 \mu \mathrm{M} \mathrm{Cd}+0 \mu \mathrm{M} \mathrm{Zn})$ was considered the control. The interpretation and normalization of the JIP test parameters were done according to Strasser et al. (2004) and Wang et al. (2016).

Statistical analysis: The experimental design was completely randomized and in a factorial scheme $(3 \times 3)$, with three concentrations of $\mathrm{Cd}(0,75$, and $150 \mu \mathrm{M})$ and three concentrations of $\mathrm{Zn}(0,750$, and 1,500 $\mu \mathrm{M})$. The obtained data were subjected to analysis of variance (ANOVA), and the means were compared by the Scott-
Knott cluster test $(p<0.05)$. The analyses were performed using the Sisvar ${ }^{\circledR}$ program (Ferreira 2011).

\section{Results}

In vitro plant growth and tolerance index: After $30 \mathrm{~d}$ of exposure of $A$. tenella plants to different concentrations of $\mathrm{Cd}$ and/or $\mathrm{Zn}$, we observed differences in morphology, growth, and the tolerance index (TI) (Fig. 1). Plants grown without $\mathrm{Zn}$ and exposed to 75 or $150 \mu \mathrm{M} \mathrm{Cd}$ showed necrosis and a mortality rate of approximately $45 \%$. Visual symptoms that indicated toxicity, such as leaf necrosis and chlorosis, were also observed in plants cultured under co-exposure to high concentrations of metals (75 or $150 \mu \mathrm{M} \mathrm{Cd}+1,500 \mu \mathrm{M} \mathrm{Zn}$ ). Regarding the growth, the total dry mass of the plants showed a decrease as a function of $\mathrm{Cd}$ concentrations when the plants were exposed to 750 and 1,500 $\mu \mathrm{M} \mathrm{Zn}$. Plants grown without $\mathrm{Cd}$ had a higher total dry mass (Fig. 1A). Cd concentrations also influenced the TI of plants, with a linear reduction as a function of $\mathrm{Cd}$ concentrations being observed. The TI was higher in plants grown without $\mathrm{Cd}$ and in those grown with $\mathrm{Zn}$ addition (Fig. 1B).

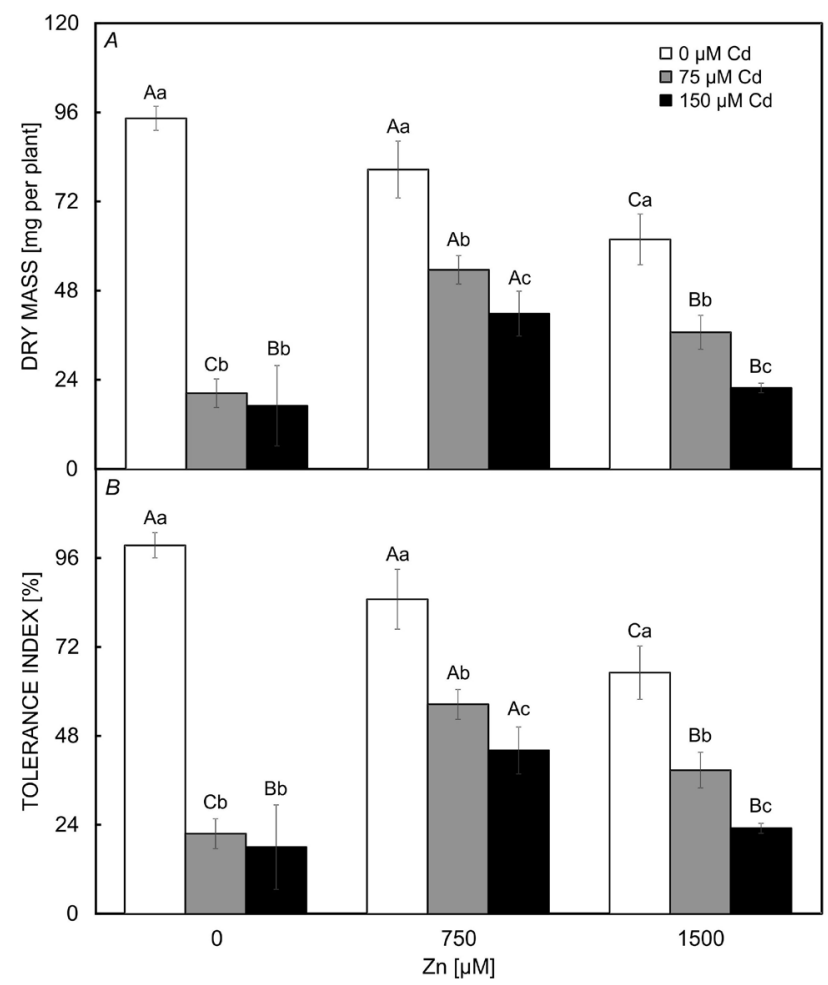

Fig. 1. Dry mass and tolerance index of Alternanthera tenella plants after $30 \mathrm{~d}$ of in vitro culture as a function of $\mathrm{Cd}(0,75$, and $150 \mu \mathrm{M})$ and $\mathrm{Zn}(0,750$, and $1,500 \mu \mathrm{M})$ concentrations. Means \pm SE $(n=5)$ followed by the same letter (uppercase letters comparing $\mathrm{Zn}$ concentrations at each $\mathrm{Cd}$ concentration and lowercase letters comparing Cd concentrations at each $\mathrm{Zn}$ concentration) do not differ significantly according to ScottKnott test $(p<0.05)$. 


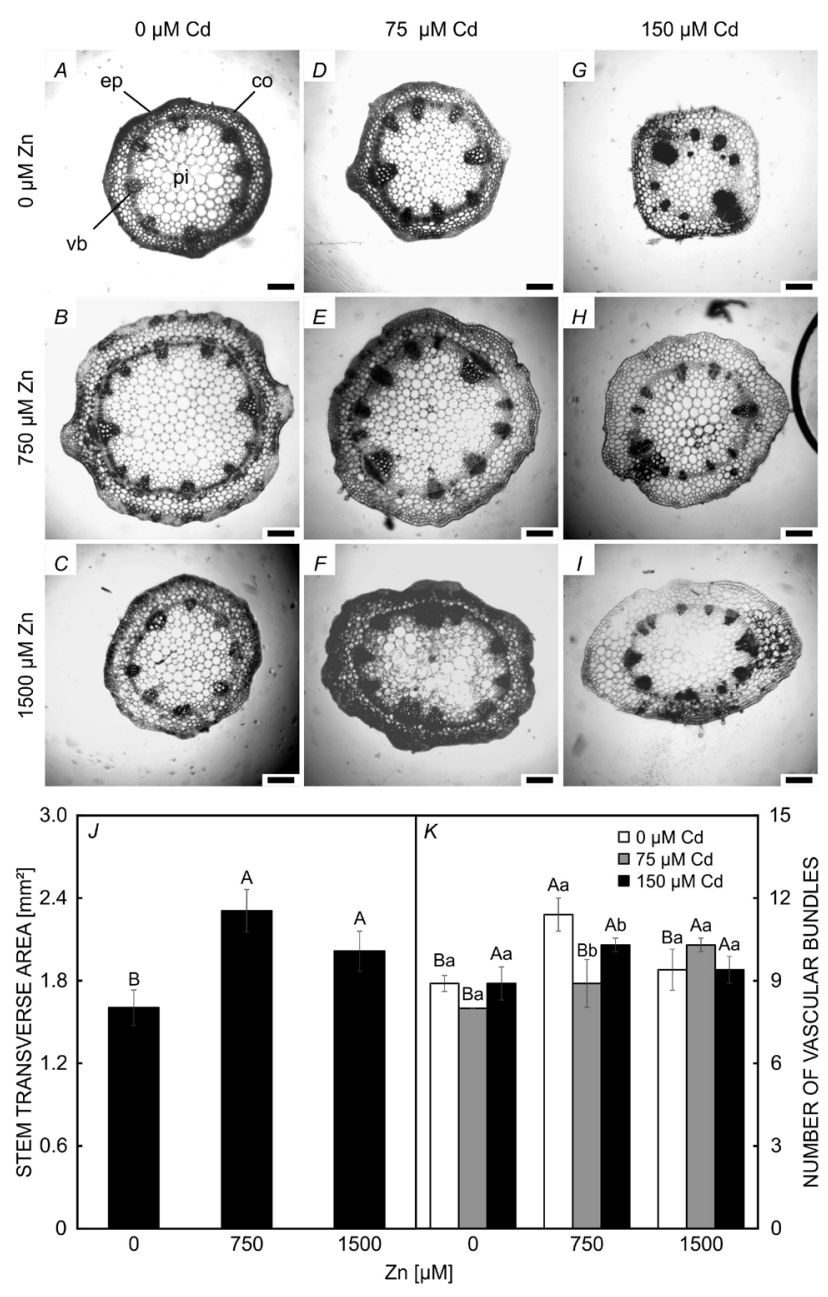

Fig. 2. Cross-sections of the stem of Alternanthera tenella plants after $30 \mathrm{~d}$ of in vitro culture as a function of the concentrations of $\mathrm{Cd}(0,75$, and $150 \mu \mathrm{M})$ and $\mathrm{Zn}(0,750$, and $1,500 \mu \mathrm{M})$. For each anatomical characteristic, the means $\pm \operatorname{SE}(n=5)$ followed by the same letter (uppercase letters comparing $\mathrm{Zn}$ concentrations and lowercase letters comparing $\mathrm{Cd}$ concentrations at each $\mathrm{Zn}$ concentration), do not differ significantly according to Scott-Knott test $(p<0.05)$. co - collenchyma; ep - epidermis; $\mathrm{vb}-$ vascular bundle; pi - pith. Bar $=200 \mu \mathrm{m}$.
Anatomical analyses (stem/leaf): Among the stem anatomy characteristics, the cross-section of the stem area was affected only by increasing $\mathrm{Zn}$ concentrations, while the number of vascular bundles was influenced by both $\mathrm{Cd}$ and $\mathrm{Zn}$ (interaction between factors). Plants grown without $\mathrm{Zn}(0 \mu \mathrm{M})$ had the lowest values for the cross-sectional area compared to plants grown with $\mathrm{Zn}$ (Fig. $2 A-J$ ). Plants grown with 0 and $1,500 \mu \mathrm{M} Z \mathrm{Zn}$ showed similar values for the number of vascular bundles. Among plants grown with $75 \mu \mathrm{M} \mathrm{Cd}$, the highest values were observed in those exposed to $1,500 \mu \mathrm{M} \mathrm{Zn}$ (Fig. $2 A-I, K$ ).

In leaves, stomata size was influenced only by $\mathrm{Cd}$ concentrations, and stomatal density was affected by both metals but independently (without interaction). Plants grown with $75 \mu \mathrm{M} \mathrm{Cd}$ had the largest stomata (Figs. 3, $4 A$ ). Stomatal density increased as a function of $\mathrm{Zn}$ concentrations. When comparing stomatal density between treatments with $\mathrm{Cd}$, a marked decrease was observed in plants exposed to this metal (Figs. 3, 4B).

The number of vessel elements, in turn, was influenced in conjunction by $\mathrm{Cd}$ and $\mathrm{Zn}$. In leaves grown in a medium without $\mathrm{Zn}$, the number of vessel elements decreased as a function of $\mathrm{Cd}$ concentrations. Furthermore, the number of vessel elements was higher in leaves grown in medium with $750 \mu \mathrm{M} \mathrm{Zn}$ and $75 \mu \mathrm{M} \mathrm{Cd}$. At the highest concentration of $\mathrm{Cd}(150 \mu \mathrm{M})$, an enhanced $\mathrm{Zn}$ concentration induced a greater number of vessel elements (Fig. 3, 4C).

Chl $\boldsymbol{a}$ fluorescence transients of plants in vitro: $\mathrm{Cd}$ and $\mathrm{Zn}$ impacted the photosynthetic apparatus of $A$. tenella plants cultured in vitro. Changes were found in all JIP test parameters and there was an interaction between $\mathrm{Cd}$ and $\mathrm{Zn}$ concentrations on all parameters related to fluorescence. Plants not exposed to $\mathrm{Cd}$ showed a reduction in $V_{K}$ and $V_{J}$ values when cultured with $\mathrm{Zn}$; however, $\mathrm{V}_{\mathrm{I}}$ values were similar regardless of $\mathrm{Zn}$ concentrations (Fig. 5). In contrast, plants exposed to $\mathrm{Cd}$ exhibited an increase in $\mathrm{V}_{\mathrm{K}}$ and $\mathrm{V}_{\mathrm{J}}$ with an increase in $\mathrm{Zn}$ concentration (Fig. $5 D, E)$. $\mathrm{V}_{\mathrm{I}}$ values were higher in plants grown with $150 \mu \mathrm{M} \mathrm{Cd}$ and/or 1,500 $\mu \mathrm{M} \mathrm{Zn} \mathrm{(Fig.} 5 F$ ).

Changes in the functionality and integrity of the thylakoid membrane $\left[\mathrm{W}_{\mathrm{L}}=\left(\mathrm{F}_{\mathrm{L}}-\mathrm{F}_{0}\right) /\left(\mathrm{F}_{\mathrm{K}}-\mathrm{F}_{0}\right)\right]$ and the oxygen-evolving complex $(\mathrm{OEC})\left[\mathrm{W}_{\mathrm{K}}=\left(\mathrm{F}_{\mathrm{K}}-\mathrm{F}_{0}\right) /\right.$

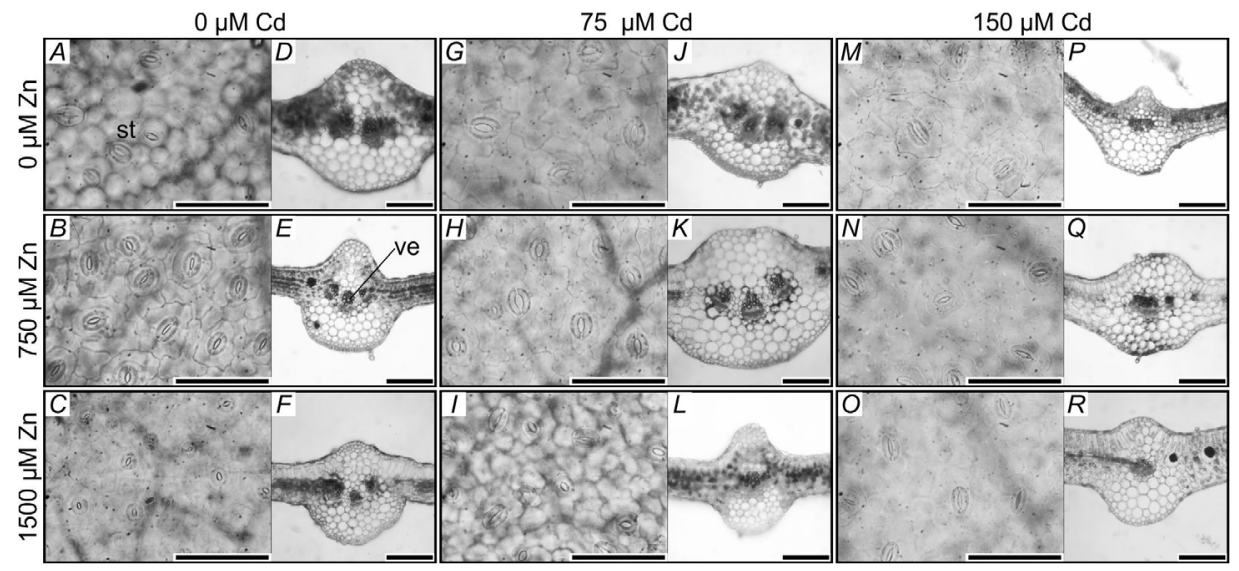

Fig. 3. Paradermal and crosssections of leaves of Alternanthera tenella plants after $30 \mathrm{~d}$ of in vitro culture as a function of concentrations of $\mathrm{Cd}(0,75$, and $150 \mu \mathrm{M})$ and $\mathrm{Zn}(0,750$, and $1,500 \mu \mathrm{M})$. st - stomata; ve - vessel element. Bar = $100 \mu \mathrm{m}$. 
$\left.\left(\mathrm{F}_{\mathrm{J}}-\mathrm{F}_{0}\right)\right]$ were influenced by both factors. Pronounced increases in $\mathrm{W}_{\mathrm{L}}$ and $\mathrm{W}_{\mathrm{K}}$ were mainly observed in plants co-exposed to $150 \mu \mathrm{M} \mathrm{Cd}$ and 750 or $1,500 \mu \mathrm{M} \mathrm{Zn}$. Similarly, increases in $\mathrm{W}_{\mathrm{L}}$ and $\mathrm{W}_{\mathrm{K}}$ values were also observed in plants grown with $75 \mu \mathrm{M} \mathrm{Cd}+1,500 \mu \mathrm{M} Z \mathrm{Zn}$. These responses were confirmed by forming positive
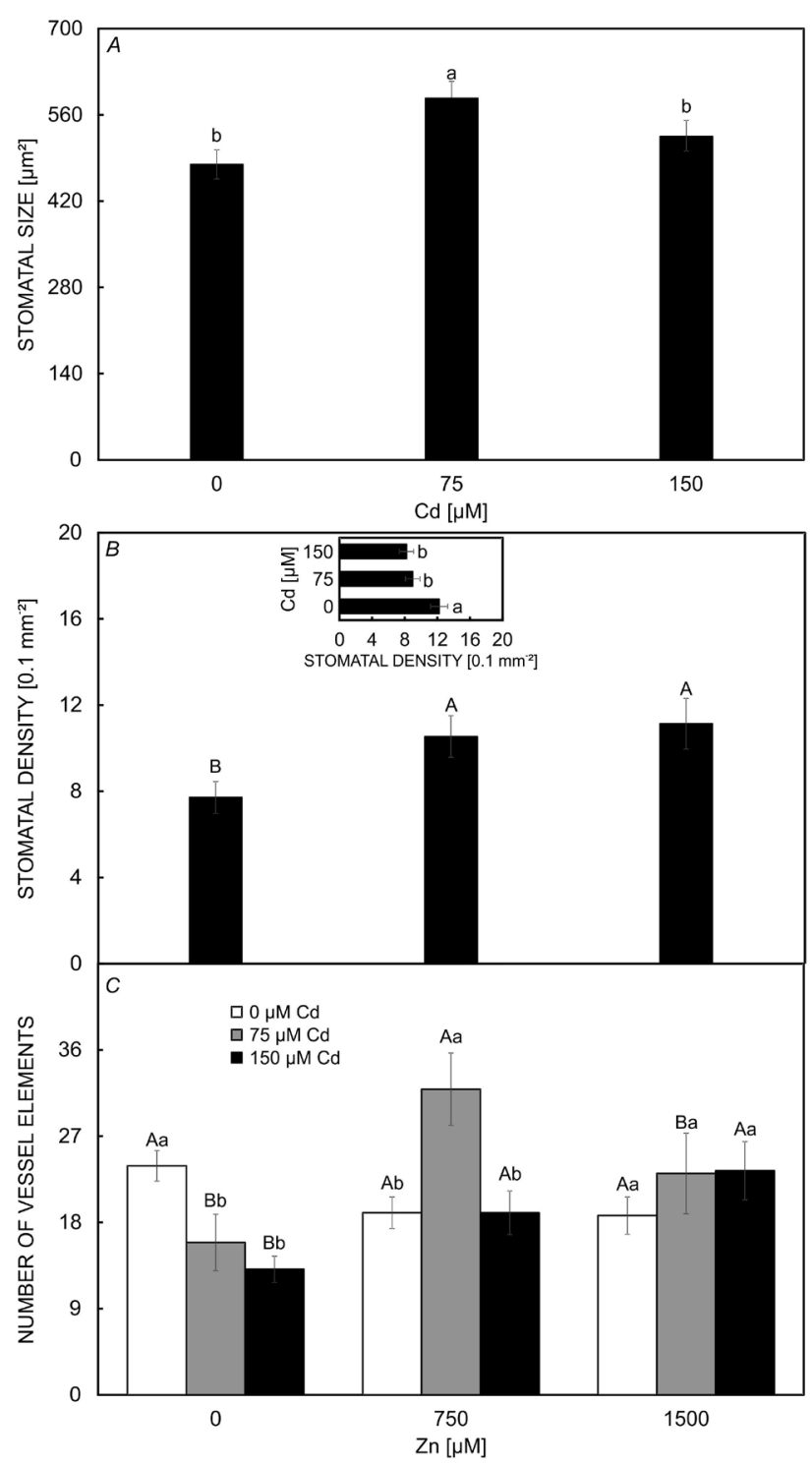

Fig. 4. Anatomical characteristics of the stem of Alternanthera tenella plants after $30 \mathrm{~d}$ of in vitro culture as a function of the concentrations of $\mathrm{Cd}(0,75$, and $150 \mu \mathrm{M})$ and $\mathrm{Zn}(0,750$, and $1,500 \mu \mathrm{M}) .(A, B)$ Size and density of $A$. tenella leaf stomata after $30 \mathrm{~d}$ of in vitro culture as a function of concentrations of $\mathrm{Cd}(0,75$, and $150 \mu \mathrm{M})$ or $\mathrm{Zn}(0,750$, and $1,500 \mu \mathrm{M})$ (without interaction). (C) The number of vessel elements of $A$. tenella leaves after $30 \mathrm{~d}$ of in vitro culture as a function of concentrations of $\mathrm{Cd}(0,75$, and $150 \mu \mathrm{M})$ and $\mathrm{Zn}(0,750$, and $1,500 \mu \mathrm{M})$ (with interaction). For each anatomical characteristic, the means \pm SE $(n=5)$ followed by the same letter (uppercase letters comparing $\mathrm{Zn}$ concentrations and lowercase letters comparing Cd concentrations), do not differ significantly according to $S$ cottKnott test $(p<0.05)$. amplitudes of L-bands and K-bands in these treatments (Fig. 6).

Changes in the $\mathrm{O}-\mathrm{I}$ phase $\left(\mathrm{V}_{\mathrm{OI}} \geq 1.0\right)$ were also verified as a function of treatments. Plants exposed to $150 \mu \mathrm{M} \mathrm{Cd}$ had a smaller amplitude compared to those grown without Cd. Plants co-exposed to $\mathrm{Cd}$ and 1,500 $\mu \mathrm{M} \mathrm{Zn}$ also showed a reduction in the amplitude of the $\mathrm{V}_{\mathrm{OI}} \geq 1.0$ curve (Fig. 7).

Reductions in $\Delta \mathrm{V}_{\mathrm{IP}}\left[=\left(\mathrm{F}_{\mathrm{P}}-\mathrm{F}_{\mathrm{I}}\right) /\left(\mathrm{F}_{\mathrm{P}}-\mathrm{F}_{0}\right)\right]$ values were observed in $150 \mu \mathrm{M} \mathrm{Cd}$ treatments, as well as in the treatment with $75 \mu \mathrm{M} \mathrm{Cd}+1,500 \mu \mathrm{M} \mathrm{Zn}$ (Fig. $8 A$ ). $A$. tenella plants grown in medium supplemented with 75 and $150 \mu \mathrm{M}$ Cd showed increased initial fluorescence $\left(\mathrm{F}_{0}\right)$ and $\mathrm{DI}_{0} / \mathrm{CSm}$. In addition, under $150 \mu \mathrm{M} \mathrm{Cd}$, there was a linear increase in $\mathrm{F}_{0}$ and $\mathrm{DI}_{0} / \mathrm{CSm}$ as a function of increasing $\mathrm{Zn}$ concentrations (Fig. $8 B, H$ ). The values of $\mathrm{F}_{\mathrm{P}}$ were the highest in plants exposed to $150 \mu \mathrm{M} \mathrm{Cd}$ (Fig. $8 C$ ).

The $F_{V} / F_{0}$ and $K_{P}$ values were higher in plants grown with $\mathrm{Zn}(750 \mu \mathrm{M}$ and $1,500 \mu \mathrm{M})$ when the media did not have $\mathrm{Cd}$ supplementation. On the other hand, in the presence of $150 \mu \mathrm{M} \mathrm{Cd}$, the plants showed a reduction in $\mathrm{F}_{\mathrm{V}} / \mathrm{F}_{0}$ and $\mathrm{K}_{\mathrm{P}}$ with an increasing concentration of $\mathrm{Zn}$ added to the culture medium (Fig. $8 D, E$ ). Regarding the quantum yield parameters, there was a significant decrease in $\varphi \mathrm{P}_{0}$ and $\varphi \mathrm{E}_{0}$ in plants grown in medium containing $75 \mu \mathrm{M} \mathrm{Cd}+750 \mu \mathrm{M} Z \mathrm{Zn}, 75$ or $150 \mu \mathrm{M} \mathrm{Cd}+1,500 \mu \mathrm{M} \mathrm{Zn}$ (Fig. $8 F, G$ ). In these treatments, an increase in $\varphi \mathrm{D}_{0}$ values was also observed (Fig. 8I). The values of $\psi R_{0}$ and $\varphi R_{0}$ decreased in plants grown in medium supplemented with $150 \mu \mathrm{M} \mathrm{Cd}$, regardless of the Zn concentration. Similarly, there was a decrease in $\psi \mathrm{R}_{0}$ and $\varphi \mathrm{R}_{0}$ in plants grown with $75 \mu \mathrm{M} \mathrm{Cd}+1,500 \mu \mathrm{M}$ Zn (Fig. $8 J, K$ ). In the Cd-free culture media, $\mathrm{Zn}$ supplementation increased the values of RC/CSm, $\mathrm{SFI}_{(\mathrm{ABS})}$, and $\mathrm{PI}_{\text {total }}$ (Fig. $8 L-N$ ). However, when $\mathrm{Cd}$ and $\mathrm{Zn}$ were added, there was a reduction in $\mathrm{RC} / \mathrm{CSm}$ and $\mathrm{SFI}_{(\mathrm{ABS})}$. Exposure to $150 \mu \mathrm{M} \mathrm{Cd}$ induced a decrease in $\mathrm{PI}_{\text {total }}$ values, with a reduction also observed in plants grown with $75 \mu \mathrm{M} \mathrm{Cd}+1,500 \mu \mathrm{M}$ Zn (Fig. $8 N$ ).

\section{Discussion}

The growth, anatomical characteristics (stem/leaves), and Chl $a$ fluorescence in A. tenella plants cultured in vitro treated with different concentrations of $\mathrm{Cd}$ and/or $\mathrm{Zn}$ were described in this study.

The decrease in total dry mass and the presence of visual symptoms such as chlorosis and necrosis in the leaves of $A$. tenella plants due to the presence of $\mathrm{Cd}$ confirmed its toxic effect. Zn did not have a pronounced negative impact on the growth and performance of the photosynthetic apparatus of the plants. The tolerance index (TI) reflected the sensitivity of $A$. tenella plants to trace elements $(\mathrm{Cd}$ and $\mathrm{Zn})$. The TI was low $(\mathrm{TI}<35)$ when the plants were grown in medium containing only $\mathrm{Cd}$, intermediate $(35<\mathrm{TI}<60)$ when they were exposed to $\mathrm{Cd}$ and $\mathrm{Zn}$, and high (TI $>60)$ when they were grown with $\mathrm{Zn}$, according to the TI described by Lux et al. (2004). The significant reduction in mass accumulation as a function of $\mathrm{Cd}$ concentrations shows the low tolerance of plants of this species to this trace element under conditions of $\mathrm{Zn}$ deficiency. In contrast, at the tested $\mathrm{Zn}$ concentrations, we 


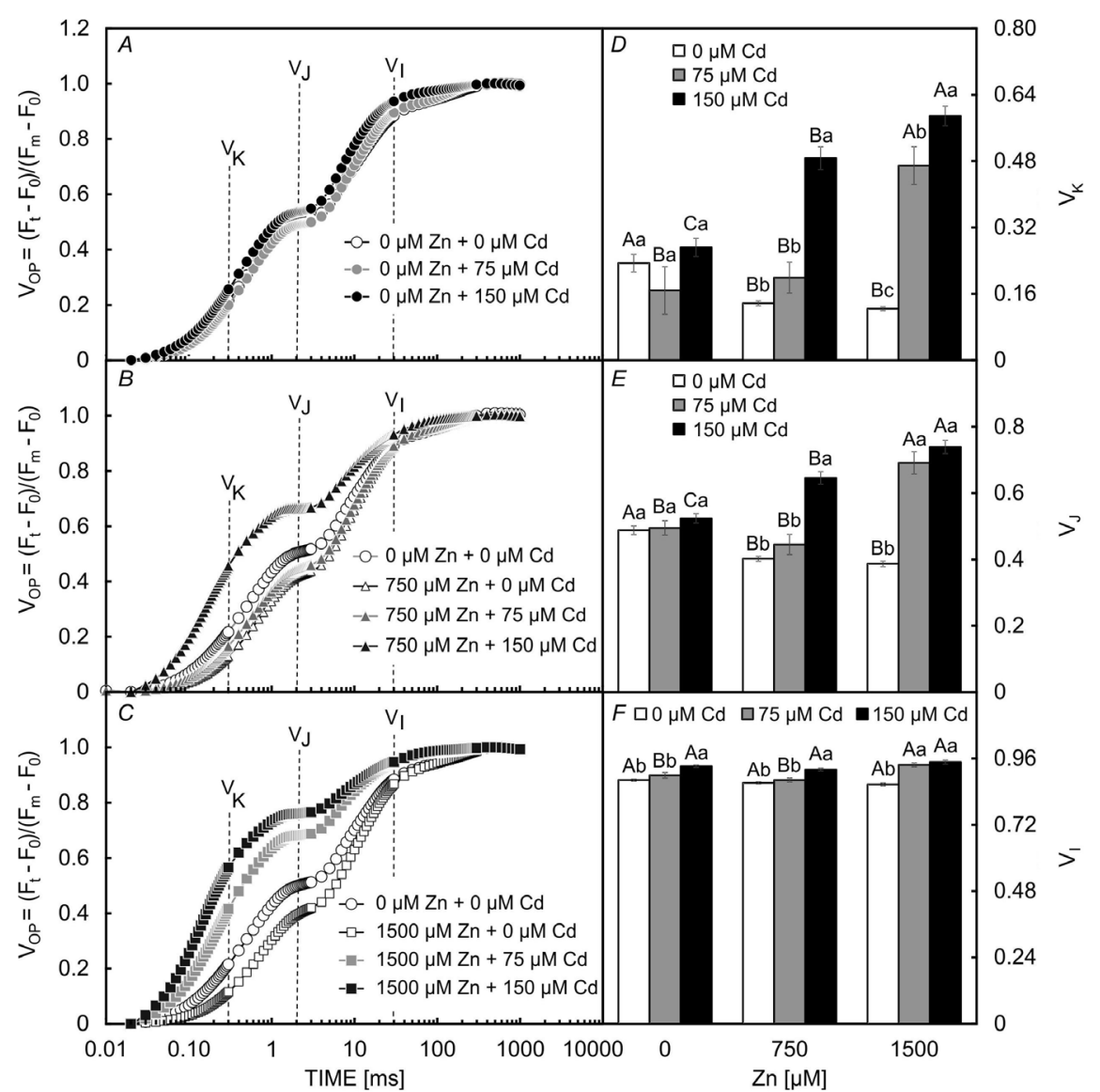

Fig. 5. Relative variable fluorescence of Alternanthera tenella plants after $30 \mathrm{~d}$ of in vitro culture as a function of concentrations of $\mathrm{Cd}(0,75$, and $150 \mu \mathrm{M})$ and $\mathrm{Zn}(0,750$, and 1,500 $\mu \mathrm{M}) .(A-C)$ Relative variable fluorescence between $\mathrm{F}_{0}$ and $\mathrm{F}_{\mathrm{m}}\left(\mathrm{V}_{\mathrm{OP}}\right)$; $(D)$ relative variable fluorescence at step $\mathrm{K}(0.3 \mathrm{~ms}) ;(E)$ variable relative fluorescence at step $\mathrm{J}(2 \mathrm{~ms}) ;(F)$ relative variable fluorescence at step I $(30 \mathrm{~ms})$. Means $\pm \operatorname{SE}(n=16)$ followed by the same letter (uppercase letters comparing $\mathrm{Zn}$ concentrations at each $\mathrm{Cd}$ concentration and lowercase letters comparing $\mathrm{Cd}$ concentrations at each $\mathrm{Zn}$ concentration) do not differ significantly according to Scott-Knott test $(p<0.05) . \mathrm{V}_{\mathrm{I}}-$ relative variable fluorescence at $30 \mathrm{~ms}$ (step I); $\mathrm{V}_{\mathrm{J}}$ - relative variable fluorescence at $2 \mathrm{~ms}$ (step J); $\mathrm{V}_{\mathrm{K}}$ - relative variable fluorescence at $0.3 \mathrm{~ms}$ (step $\mathrm{K})$. can suggest that $\mathrm{Zn}$ (at concentrations up to $750 \mu \mathrm{M}$ ) was partially effective to mitigate Cd stress. Similar effects on in vitro culture growth were reported by Pérez-Romero et al. (2016) and Wiszniewska et al. (2017), showing that the toxicity of $\mathrm{Cd}$ usually results in growth disorders due to its easy accumulation in plant tissues and, therefore, it harms essential physiological processes. On the other hand, $\mathrm{Zn}$ is a micronutrient and can play an important role in plants, increasing the biomass of aerial parts and roots and facilitating the photolysis of water during photosynthesis (Abbas et al. 2017, Wu et al. 2020).

The anatomical characteristics of $A$. tenella plants are consistent with the literature. The morphological responses of $A$. tenella plants were also described under exposure to other trace elements under in vitro conditions (Rodrigues et al. 2017, Martins et al. 2020).

Exposure to $\mathrm{Zn}$ stimulated the increase in the crosssectional area of the stem; however, this element did not have a major impact on the formation of vascular bundles in this organ. The increase in the cross-sectional area appears to be related to the role of $\mathrm{Zn}$ in cell division of the cortex and pith. This element is involved in the synthesis of tryptophan (auxin precursor), cell division, and maintenance of the membrane structure (Lacerda et al. 2018). However, at high concentrations, Zn can induce changes in the process of cell division and inhibition of cell elongation (Somavilla et al. 2018, Alam et al. 2020). This statement makes sense since plants grown with
$1,500 \mu \mathrm{M} Z \mathrm{Zn}$ showed a decreasing trend in cross-sectional area. Thus, at higher concentrations than those tested, the plants would possibly show a more significant reduction in the cross-sectional area of the stem.

In leaves, stomatal morphology and density changes are typical responses of plants to stress conditions, such as water deficit or exposure to trace elements (Andrade et al. 2019, Caine et al. 2019, Pires-Lira et al. 2020). Cd induced an antagonistic response to that of $\mathrm{Zn}$. Exposure to $75 \mu \mathrm{M} \mathrm{Cd}$ led to the formation of larger stomata, which can influence $\mathrm{CO}_{2}$ absorption and transpiration. Smaller stomata tend to be more functional, but this can also interfere with mass flux by modulating transpiration (Pereira et al. 2016, Martins et al. 2019). The reduction in stomata density and a decrease in the number of vessel elements may indicate a response to $\mathrm{Cd}$ that led to a reduction in mass flux. It can influence the uptake and translocation of $\mathrm{Cd}$ (among other nutrients) from the culture medium to the aerial part of the plants. This may be related to a strategy of plants to resist or adapt to excess trace elements (Wafee et al. 2018).

The number of vessel elements in leaves can control the translocation of elements absorbed by the roots to the aerial part (Martins et al. 2016, Rodrigues et al. 2017). A reduction in nutrient translocation from the medium may have impaired mass accumulation, the amount of water needed for the photosynthetic reaction, and reduced performance of the photosynthetic apparatus. 

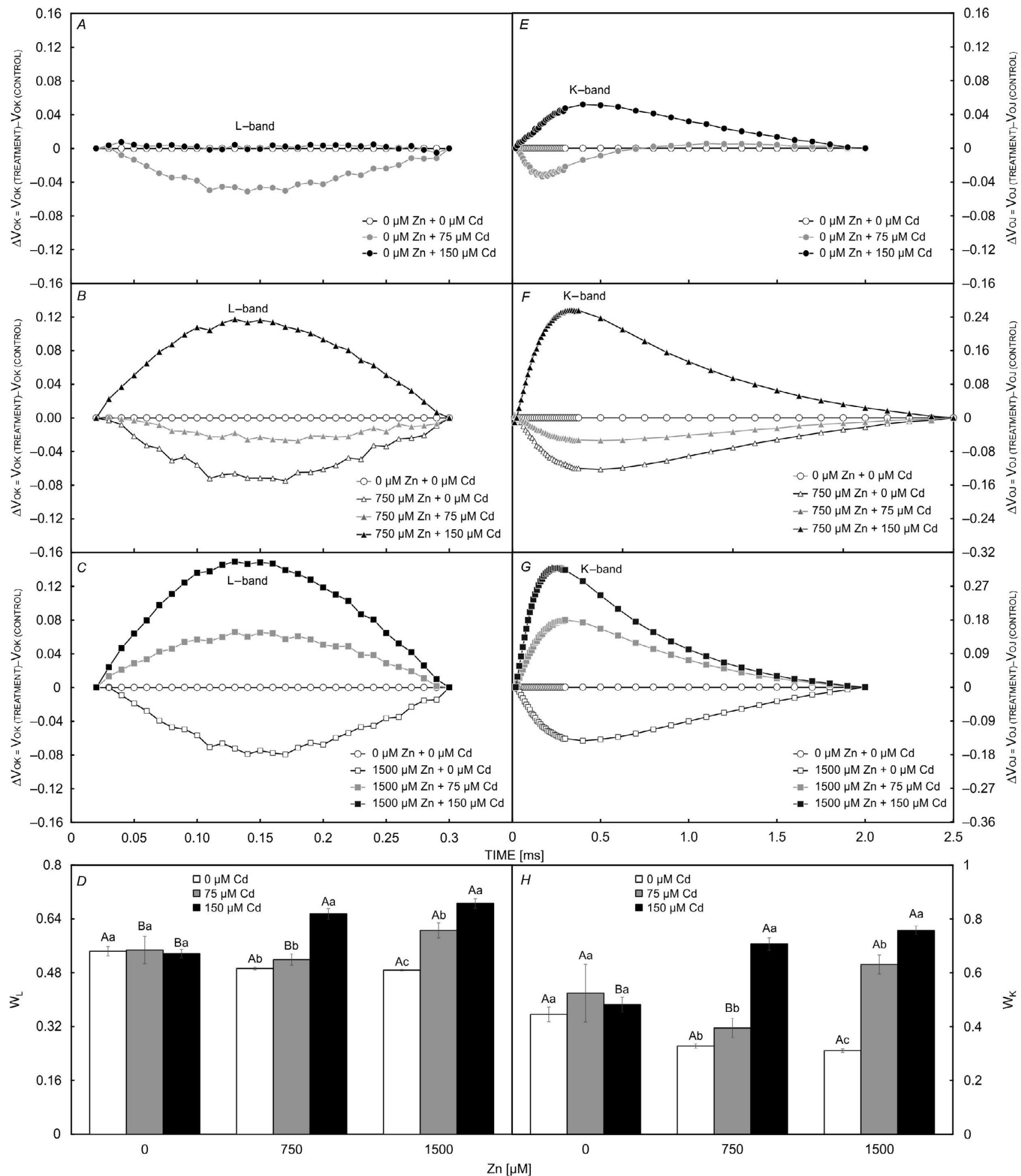

Fig. 6. Transient chlorophyll $a$ fluorescence between points $\mathrm{O}-\mathrm{K}$ and $\mathrm{O}-\mathrm{J}$ of Alternanthera tenella plants after $30 \mathrm{~d}$ of in vitro culture as a function of concentrations of $\mathrm{Cd}(0,75$, and $150 \mu \mathrm{M})$ and $\mathrm{Zn}(0,750$, and 1,500 $\mu \mathrm{M})$. $(A-C)$ Kinetic differences between points $\mathrm{O}$ and $\mathrm{K}$, showing the L-band; $(D) \mathrm{W}_{\mathrm{L}}$ values (indicates a disturbance in the thylakoid membranes, reducing the energetic connectivity between the PSII units). ( $E-G)$ Kinetic differences between points $\mathrm{O}$ and $\mathrm{J}$, showing the $\mathrm{K}$-band; $(H) \mathrm{W}_{\mathrm{K}}$ values (represents the damage to oxygen-evolving complex). Means $\pm \mathrm{SE}(n=16)$ followed by the same letter (uppercase letters comparing $\mathrm{Zn}$ concentrations at each $\mathrm{Cd}$ concentration and lowercase letters comparing $\mathrm{Cd}$ concentrations at each $\mathrm{Zn}$ concentration) do not differ significantly according to Scott-Knott test $(p<0.05)$. 
In plants grown without $\mathrm{Zn}$, we observed a reduction in the number of vessel elements as a function of $\mathrm{Cd}$ concentrations. The effects of Cd toxicity on A. tenella leaf tissues have also been shown by Rodrigues et al. (2017). $\mathrm{Cd}$ can inhibit cell division as well as alter the cell cycle in leaf tissues (Hendrix et al. 2018).

The damage observed in the anatomy and morphology of the plants was reflected in the plant physiology. An increase in $\mathrm{V}_{\mathrm{K}}$ and $\mathrm{V}_{\mathrm{J}}$ can indicate damage to the system involved in the oxidation of water molecules of PSII and partial blockage of electron transfer from $Q_{A}$ to $Q_{B}$ in the electron transport chain at the acceptor side of PSII, respectively (Kalaji et al. 2016, Zhang et al. 2016). In this context, the decrease in $\mathrm{V}_{\mathrm{K}}$ and $\mathrm{V}_{\mathrm{J}}$ values observed in plants grown only with $\mathrm{Zn}$ may indicate an improvement in the activities of the oxygen-evolving complex (OEC) on the electron donor side of PSII and the essentiality of this

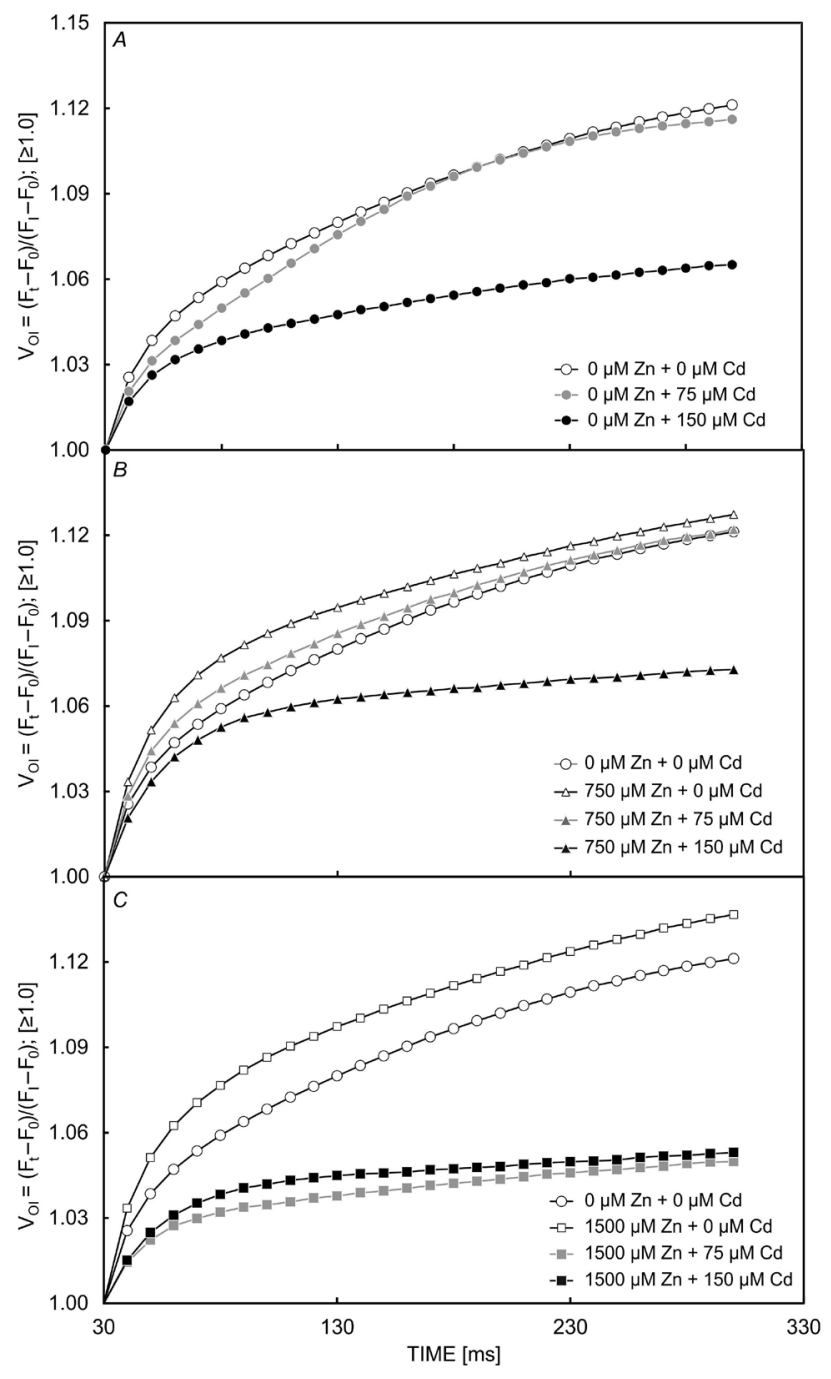

Fig. 7. Normalization of transient chlorophyll $a$ fluorescence between $\mathrm{F}_{0}$ and $\mathrm{F}_{\mathrm{I}}\left(\mathrm{V}_{\mathrm{OI}} \geq 1.0\right)$ of Alternanthera tenella plants after $30 \mathrm{~d}$ of in vitro culture as a function of concentrations of $\mathrm{Cd}$ $(0,75$, and $150 \mu \mathrm{M})$ and $\mathrm{Zn}(0,750$, and $1,500 \mu \mathrm{M})$. element for good performance of primary photochemical activities. In contrast, the increase in $V_{K}$ and $V_{J}$ values observed as a function of $\mathrm{Cd}$ concentrations in conjunction with $1,500 \mu \mathrm{M} \mathrm{Zn}$ indicates the occurrence of disorders in OEC activity or a reduction in $\mathrm{Q}_{\mathrm{A}}^{-}$accompanied by a weak transfer of electrons to $\mathrm{Q}_{\mathrm{B}}$, resulting in higher fluorescence emission (Martins et al. 2020). Concerning this fact, the effects of $\mathrm{Cd}$ are manifested both on the donor and on the acceptor side of PSII and affect the activities of the photosynthetic apparatus. Thus, although toxic at high concentrations, $\mathrm{Zn}$ is presented in this study as an element mitigating Cd-induced stress in $A$. tenella plants and plays a key role in photosynthesis and electron transport.

The formation of a positive L-band can signal disorders and weak connectivity between PSII subunits or even damage to thylakoid membranes (Paunov et al. 2018, Zhang et al. 2018). The increase in $\mathrm{W}_{\mathrm{L}}$ values of plants grown with high concentrations of $\mathrm{Zn}(1,500 \mu \mathrm{M})$ and $\mathrm{Cd}$ confirmed this result. The presence of both trace elements in excess caused harmful effects to electron transport linked to poor performance of the photosynthetic apparatus. Thus, our results suggest that plants co-exposed to high concentrations of both trace elements can show damage to their thylakoid membranes and consequent impairment of the electron transport chain. It could be related to $\mathrm{Chl}$ content, as reported for $A$. tenella plants under concentrations higher than $50 \mu \mathrm{M} \mathrm{Cd}$ and excess Zn (Rodrigues et al. 2017). At high concentrations, these trace elements can disrupt the chloroplast ultrastructure, dismantle the thylakoid, reduce the Chl biosynthesis, and impair the electron transport and the connectivity between the PSII subunits (Amari et al. 2017, Adamakis et al. 2021, Janeeshma et al. 2021, Rajput et al. 2021).

The presence of positive K-bands can also indicate physiological disorders in PSII related to damage of the OEC (Kalaji et al. 2016). Wang et al. (2017b) and Zhang et al. (2018) reported an increase in $\mathrm{W}_{\mathrm{K}}$, representing damage in the transport of electrons from OEC to $\mathrm{P}_{680}{ }^{+}$. It represents an important target for metallic contaminants because the inhibition of the biochemical and biophysical processes of photosynthesis affects, in particular, the physiology of the whole plant. In the present study, the presence of $\mathrm{Zn}$ in plants grown with $75 \mu \mathrm{M} \mathrm{Cd}$ showed better performance of the thylakoid membranes and the OEC at the donor side of PSII, evidenced by the presence of negative L-band and K-band. It also indicates improved energy absorption, activities, and connectivity between PSII units.

The O-I and I-P phases are associated with electron transfer dynamics from the intersystem to PSI (Souza et al. 2019). Reduction of amplitudes in the O-I interval $\left(\mathrm{V}_{\mathrm{OI}} \geq 1.0\right)$ was observed when plants were co-exposed to high concentrations of the two trace elements. This decrease in the values of $\mathrm{V}_{\mathrm{OI}} \geq 1$ may indicate a reduction in electron flux and pool size of the final electron acceptors of PSI (Yusuf et al. 2010, Souza et al. 2019). The damages induced by excess $\mathrm{Cd}$ led to a reduction in $\Delta \mathrm{V}_{\mathrm{IP}}$ values, suggesting a smaller contribution of emission of Chl $a$ fluorescence and reduction in PSI units (Paunov et al. 2018). Thus, excess $\mathrm{Cd}$ and $\mathrm{Zn}$ in plants can lead to disorders in the photosynthetic apparatus. 


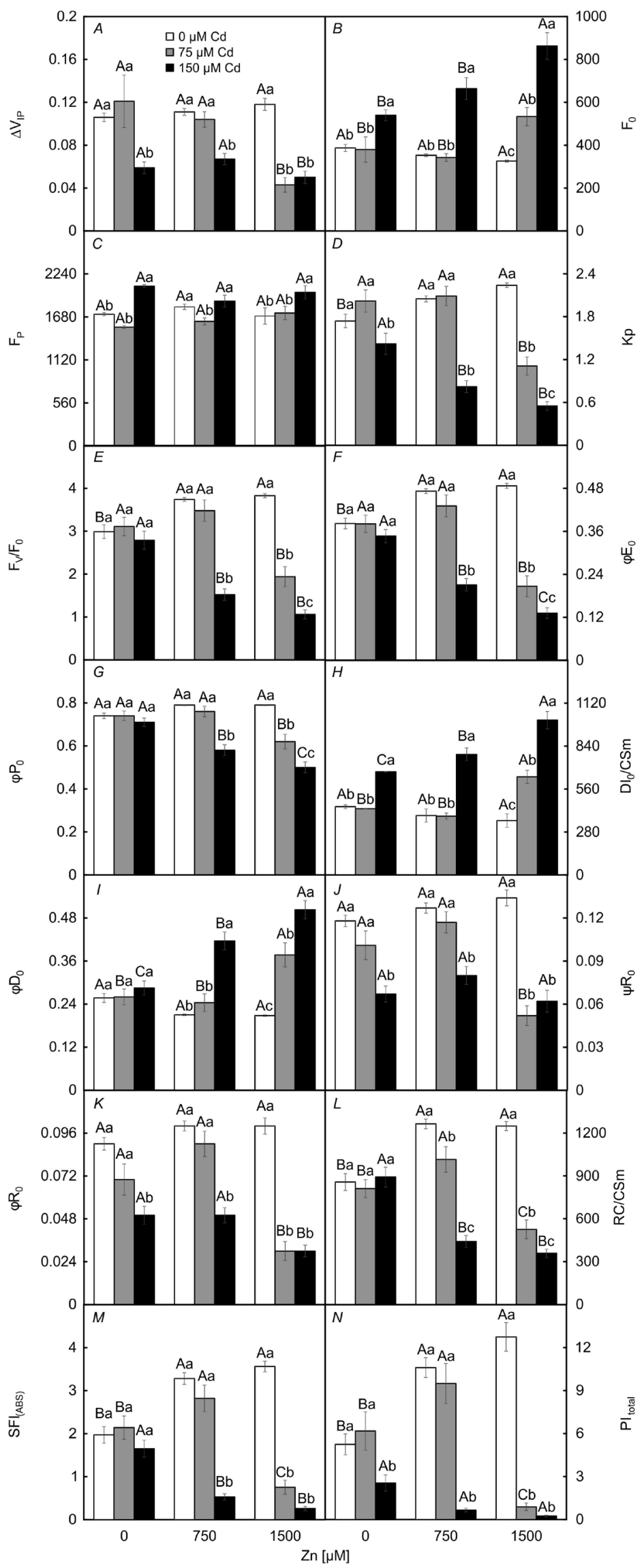

Fig. 8. Amplitude of the relative variable fluorescence of the increase from I to $\mathrm{P}\left(\Delta \mathrm{V}_{\text {IP }}\right)$ and JIP test parameters of Alternanthera tenella plants after $30 \mathrm{~d}$ of in vitro culture as a function of concentrations of $\mathrm{Cd}(0,75$, and $150 \mu \mathrm{M})$ and $\mathrm{Zn}(0,750$, and $1,500 \mu \mathrm{M})$. Means \pm SE $(n=16)$ followed by the same letter (uppercase letters comparing $\mathrm{Zn}$ concentrations at each $\mathrm{Cd}$ concentration and lowercase letters comparing $\mathrm{Cd}$ concentrations at each $\mathrm{Zn}$ concentration) do not differ significantly according to Scott-Knott test $(p<0.05)$. $\mathrm{DI}_{0} / \mathrm{CSm}$ - dissipated energy flux per cross-section; $\mathrm{F}_{0}$ - initial fluorescence; $\mathrm{F}_{\mathrm{P}}$ - fluorescence peak; $\mathrm{F}_{\mathrm{V}} / \mathrm{F}_{0}$ - ratio of the de-excitation rate constants for photochemical and nonphotochemical events; $\mathrm{K}_{\mathrm{P}}-$ photochemical de-excitation rate constant; $\mathrm{PI}_{\text {total }}$ - total performance index, which measures the performance up until the final electron acceptors of PSI; RC/CSm total number of active reaction centers; $\mathrm{SFI}_{(\mathrm{ABS})}-$ PSII structure and functioning index; $\Delta \mathrm{V}_{\mathrm{IP}}$ - relative variable fluorescence amplitude of the increase from I to $\mathrm{P}=$ relative contribution of the increase from $\mathrm{I}$ to $\mathrm{P}$ to the increase in OJIP; $\varphi \mathrm{D}_{0}$ - quantum yield of energy dissipation (at $\mathrm{t}=0) ; \varphi \mathrm{E}_{0}$ - quantum yield of electron transport (at $\mathrm{t}=0) ; \varphi \mathrm{P}_{0}-$ maximum quantum yield of primary photochemistry (at $t=0) ; \varphi R_{0}$ - quantum yield of reduction of end electron acceptors at the PSI acceptor side (RE); $\psi \mathrm{R}_{0}$ - efficiency/probability by which electrons move from PSII to PSI acceptor side. 
The PSII, intersystem, and PSI activities, as a function of the treatments, were also expressed through the JIP test parameters. An increase in $\mathrm{F}_{0}$ can signal a reduction in a number of active reaction centers (RCs), reflecting a decrease in the constant rate of trapped energy (Lotfi et al. 2018). In this work, plants exposed to high concentrations of $\mathrm{Cd}$ and $\mathrm{Zn}$ presented increased $\mathrm{F}_{0}$ values and reduced $\mathrm{RC} / \mathrm{CSm}$, followed by a high energy dissipation as shown by $\mathrm{DI}_{0} / \mathrm{CSm}$ values (low rate of trapped energy). Furthermore, with the increase in $\mathrm{F}_{0}$ and the decrease in the $F_{V} / F_{0}$ ratio values, it was possible to verify that plants exposed to high concentrations of $\mathrm{Cd}$ presented a reduction in the constant rate of trapped energy in PSII centers. A decrease in $K_{P}$ values may reflect abundant energy loss in plants under trace element stress or signal damage to PSII centers (Kumar et al. 2020). Reduced $F_{V} / F_{0}$ values may reflect the decline in electron transport resulting from low OEC activity for the donor side of PSII or a decrease in trapped energy in the RCs of PSII (Ghassemi-Golezani and Lotfi 2015, Pontes et al. 2020), which corroborates the increased values of $\mathrm{W}_{\mathrm{K}}$. The higher values of $\mathrm{F}_{\mathrm{V}} / \mathrm{F}_{0}$ and $\mathrm{K}_{\mathrm{P}}$, in addition to the decreased values of $\mathrm{W}_{\mathrm{K}}$, observed in plants grown with $\mathrm{Zn}$ without $\mathrm{Cd}$ supplementation, proved the positive effects of this trace element during the in vitro culture of $A$. tenella.

Under co-exposure to both trace elements at high concentrations, the plants also presented decreased quantum yield $\left(\varphi \mathrm{P}_{0}\right.$ and $\left.\varphi \mathrm{E}_{0}\right)$, thus showing a state of stress in the plants. Meng et al. (2016) and Kalisz et al. (2016) reported that a decrease in quantum yield values might be the result of photoinhibition due to photochemical damage in PSII. In addition, a reduction of $\varphi \mathrm{E}_{0}$ values indicates a lower efficiency in electron transport, especially from $\mathrm{Q}_{\mathrm{A}}$ to $\mathrm{Q}_{\mathrm{B}}$ (Kalaji et al. 2016). In contrast, an increase in $\varphi \mathrm{P}_{0}$ and $\varphi \mathrm{E}_{0}$ may reflect better electron transfer between $\mathrm{Q}_{\mathrm{A}}$ and $\mathrm{Q}_{\mathrm{B}}$, with a high connection between the PSII antennas (Lotfi et al. 2018, Singh et al. 2018).

In this study, $A$. tenella plants grown in media with co-exposure to both trace elements at high concentrations presented physiological disorders resulting in the inactivation of RCs (as evidenced by RC/CSm values), which led to a greater dissipation of energy $\left(\varphi \mathrm{D}_{0}\right)$. The inactivation of RCs is a negative response induced by stress caused by trace elements (Meng et al. 2016, Zhang et al. 2017). In this situation, Paunov et al. (2018) stated that a smaller number of active RCs would indicate that less energy is used in the electron transport system, thus, the unused energy must be dissipated. A decrease in $\mathrm{RC} / \mathrm{CSm}$ values is usually accompanied by increased values of $\mathrm{F}_{0}$ and $\varphi \mathrm{D}_{0}$. Increased $F_{0}$ and $\varphi D_{0}$ values reflect a reduction in the dynamics of transport and use of excitation energy, which may reflect a greater dissipation of energy in the form of heat (Meng et al. 2016). This response was even higher in plants exposed to $150 \mu \mathrm{M} \mathrm{Cd}$, which presented high values of $\mathrm{F}_{0}$ and simultaneously increased $\mathrm{F}_{\mathrm{P}}$, which can indicate low energy trapping efficiency in the RCs (Martins et al. 2015). It led to an increase in $\mathrm{DI}_{0} / \mathrm{CSm}$ and reduced $\mathrm{PI}_{\text {total }}$. Higher energy dissipation $\left(\mathrm{DI}_{0} / \mathrm{CSm}\right)$ can reduce the energy necessary for photochemical transformations (Pastuszak et al. 2020).
The $\psi \mathrm{R}_{0}$ parameter is sensitive to the effect of trace elements and is associated with a significant decrease in PSI activity. A decrease in $\psi R_{0}$ under exposure to high concentrations of trace elements may indicate a decrease in efficiency or probability of transfer of trapped electrons from PSII to PSI (Rastogi et al. 2019, Faseela et al. 2020). This response occurs by the increase in $\mathrm{V}_{\mathrm{I}}$. Other parameters also confirmed that the negative effects of excess trace elements went beyond PSII in A. tenella plants. This lower efficiency of the photosynthetic apparatus beyond the intersystem was confirmed by the reduced values of $\varphi R_{0}$. The decrease in the values of this parameter may indicate photoinhibition with lower efficiency of PSII electrons to reach the final electron acceptors of PSI (Wang et al. 2017b, Zhuo et al. 2017, Chattopadhyay et al. 2020).

The mitigating effect of $\mathrm{Zn}$ and its essentiality as a micronutrient was evidenced by the $\mathrm{PI}_{\text {total }}$ and $\mathrm{SFI}_{(\mathrm{ABS})}$ parameters. The increased values of these parameters in A. tenella plants grown with $\mathrm{Zn}$, even when co-exposed to $75 \mu \mathrm{M} \mathrm{Cd}$, demonstrated how this micronutrient acts positively on the dynamics of electron transport from PSII to PSI. However, it should be noted that $\mathrm{Zn}$ at high concentrations can increase the Cd-induced stress in plants. The $\mathrm{PI}_{\text {total }}$ and $\mathrm{SFI}_{(\mathrm{ABS})}$ parameters are good indicators of photosynthetic performance. They specify how stressors acted on the efficiency and functionality of the photosynthetic apparatus of plants (Yusuf et al. 2010, Kalaji et al. 2016). The decrease in $\mathrm{SFI}_{(\mathrm{ABS})}$ observed in plants without $\mathrm{Zn}$ or with the highest concentration of $\mathrm{Cd}$ demonstrated instability and difficulty for the plants to conserve energy and promote a decreased PSII performance (Stirbet et al. 2018). This may lead to an interruption in the electron transport rate and the general photosynthetic activity of several plants (Gupta 2020). Thus, a decrease in the overall performance of the photosynthetic apparatus is expected, as seen through the reduced values of $\mathrm{PI}_{\text {total }}$. Furthermore, lower values of $\mathrm{PI}_{\text {total }}$ indicated that the damage went beyond the intersystem and negatively affected the overall performance of the photosynthetic apparatus.

Conclusion: Cd induced an antagonistic response to that of $\mathrm{Zn}$. With exposure only to $\mathrm{Cd}$, plants showed physiological disorders and reduced plant growth. $\mathrm{Zn}$ increased the cross-sectional area of the stem and had positive effects on the physiological performance of plants, such as stability in the structure and functionality of the photosynthetic apparatus. The co-exposure to both trace elements at high concentrations resulted in the inactivation of RCs $(\mathrm{RC} / \mathrm{CSm})$ and greater dissipation of energy $\left(\varphi \mathrm{D}_{0}\right.$ and $\left.\mathrm{DI}_{0} / \mathrm{CSm}\right)$. Exposure to $\mathrm{Zn}$ at concentrations $\leq 750 \mu \mathrm{M}$ may partially mitigate the deleterious effects of the $\mathrm{Cd}$ concentrations evaluated. Therefore, from an ecotoxicological point of view, the excess of both trace elements $(\mathrm{Cd}$ and $\mathrm{Zn})$ represents toxicity to the species under study.

\section{References}

Abbas M.S., Akmal M., Ullah S. et al.: Effectiveness of zinc and gypsum application against cadmium toxicity and 
accumulation in wheat (Triticum aestivum L.). - Commun. Soil Sci. Plant Anal. 48: 1659-1668, 2017.

Adamakis I.D.S., Sperdouli I., Hanć A. et al.: Rapid hormetic responses of photosystem II photochemistry of clary sage to cadmium exposure. - Int. J. Mol. Sci. 22: 41, 2021.

Adhikari T., Kundu S., Rao A.S.: Zinc delivery to plants through seed coating with nano-zinc oxide particles. - J. Plant Nutr. 39: 136-146, 2016.

Ahmad A., Hadi F., Ali N.: Effective phytoextraction of cadmium (Cd) with increasing concentration of total phenolics and free proline in Cannabis sativa (L) plant under various treatments of fertilizers, plant growth regulators and sodium salt. - Int. J. Phytoremediat. 17: 56-65, 2015.

Alam N., Anis M., Javed S.B., Alatar A.A.: Stimulatory effect of copper and zinc sulphate on plant regeneration, glutathioneS-transferase analysis and assessment of antioxidant activities in Mucuna pruriens L. (DC). - Plant Cell Tiss. Org. Cult. 141: $155-166,2020$.

Alloway B.J.: Heavy Metals in Soils: Trace Metals and Metalloids in Soils and their Bioavailability. Pp. 614. Springer, Dordrecht 2013.

Amari T., Ghnaya T., Abdelly C.: Nickel, cadmium and lead phytotoxicity and potential of halophytic plants in heavy metal extraction. - S. Afr. J. Bot. 111: 99-110, 2017.

Andrade Júnior W.V., Oliveira Neto C.F., Santos Filho B.G. et al.: Effect of cadmium on young plants of Virola surinamensis. AoB Plants 11: plz022, 2019.

Ayangbenro A.S., Babalola O.O.: A new strategy for heavy metal polluted environments: a review of microbial biosorbents. Int. J. Environ. Res. Public Health 14: 94, 2017.

Caine R.S., Yin X., Sloan J. et al.: Rice with reduced stomatal density conserves water and has improved drought tolerance under future climate conditions. - New Phytol. 221: 371-384, 2019.

Carolin C.F., Kumar P.S., Saravanan A. et al.: Efficient techniques for the removal of toxic heavy metals from aquatic environment: A review. - J. Environ. Chem. Eng. 5: 27822799, 2017.

Chattopadhyay K., Vijayan J., Ray A. et al.: Additive main effect and digenic epistatic quantitative trait loci for chlorophyll fluorescence traits influencing salt tolerance at seedling stage in rice. - Photosynthetica 58: 595-607, 2020.

Du J., Zeng J., Ming X. et al: The presence of zinc reduced cadmium uptake and translocation in Cosmos bipinnatus seedlings under cadmium/zinc combined stress. - Plant Physiol. Bioch. 151: 223-232, 2020.

Faseela P., Sinisha A.K., Brestič M., Puthur J.T.: Chlorophyll $a$ fluorescence parameters as indicators of a particular abiotic stress in rice. - Photosynthetica 58: 293-300, 2020.

Ferreira D.F.: Sisvar: a computer statistical analysis system. Ciênc. Agrotec. 35: 1039-1042, 2011.

Ghassemi-Golezani K., Lotfi R.: The impact of salicylic acid and silicon on chlorophyll $a$ fluorescence in mung bean under salt stress. - Russ. J. Plant Physiol. 62: 611-616, 2015.

Gupta R.: The oxygen-evolving complex: a super catalyst for life on earth, in response to abiotic stresses. - Plant Signal. Behav. 15: 1824721, 2020.

Hendrix S., Keunen E., Mertens A.I.G. et al.: Cell cycle regulation in different leaves of Arabidopsis thaliana plants grown under control and cadmium-exposed conditions. - Environ. Exp. Bot. 155: 441-452, 2018.

Janeeshma E., Kalaji H.M., Puthur J.T.: Differential responses in the photosynthetic efficiency of Oryza sativa and Zea mays on exposure to $\mathrm{Cd}$ and $\mathrm{Zn}$ toxicity. - Acta Physiol. Plant. 43: $12,2021$.

Jeong H., Choi J.Y., Lee J. et al.: Heavy metal pollution by roaddeposited sediments and its contribution to total suspended solids in rainfall runoff from intensive industrial areas. Environ. Pollut. 265: 115028, 2020.

Johansen D.A.: Plant Microtechnique. Pp. 487. McGraw-Hill, New York-London 1940.

Kalaji H.M., Jajoo A., Oukarroum A. et al: Chlorophyll a fluorescence as a tool to monitor physiological status of plants under abiotic stress conditions. - Acta Physiol. Plant. 38: 102, 2016.

Kalisz A., Jezdinský A., Pokluda R. et al.: Impacts of chilling on photosynthesis and chlorophyll pigment content in juvenile basil cultivars. - Hortic. Environ. Biote. 57: 330-339, 2016.

Karri V., Kumar V., Ramos D. et al.: Comparative in vitro toxicity evaluation of heavy metals (lead, cadmium, arsenic, and methylmercury) on HT-22 hippocampal cell line. - Biol. Trace Elem. Res. 184: 226-239, 2018.

Kirkby E.: Introduction, definition and classification of nutrients. - In: Marschner H. (ed.): Marschner's Mineral Nutrition of Higher Plants. Pp. 3-5. Academic Press, Amsterdam 2012.

Kumar D., Singh H., Raj S., Soni V.: Chlorophyll $a$ fluorescence kinetics of mung bean (Vigna radiata L.) grown under artificial continuous light. - Biochem. Biophys. Rep. 24: 100813, 2020

Lacerda J.S., Martinez H.E.P., Pedrosa A.W. et al.: Importance of zinc for arabica coffee and its effects on the chemical composition of raw grain and beverage quality. - Crop Sci. 58: 1360-1370, 2018.

Lange B., van der Ent A., Baker A.J.M. et al.: Copper and cobalt accumulation in plants: a critical assessment of the current state of knowledge. - New Phytol. 213: 537-551, 2017.

Logiewa A., Miazgowicz A., Krennhuber K, Lanzerstorfer C.: Variation in the concentration of metals in road dust size fractions between $2 \mu \mathrm{m}$ and $2 \mathrm{~mm}$ : Results from three metallurgical centres in Poland. - Arch. Environ. Con. Tox. 78: 46-59, 2020.

Lotfi R., Kalaji H.M., Valizadeh G.R. et al.: Effects of humic acid on photosynthetic efficiency of rapeseed plants growing under different watering conditions. - Photosynthetica 56: 962-970, 2018.

Lux A., Šottníková A., Opatrná J., Greger M.: Differences in structure of adventitious roots in Salix clones with contrasting characteristics of cadmium accumulation and sensitivity. Physiol. Plantarum 120: 537-545, 2004.

Martins J.P.R., Martins A.D., Pires M.F. et al.: Anatomical and physiological responses of Billbergia zebrina (Bromeliaceae) to copper excess in a controlled microenvironment. - Plant Cell Tiss. Org. Cult. 126: 43-57, 2016.

Martins J.P.R., Rodrigues L.C.A., Silva T.S. et al.: Sources and concentrations of silicon modulate the physiological and anatomical responses of Aechmea blanchetiana (Bromeliaceae) during in vitro culture. - Plant Cell Tiss. Org. Cult. 137: 397-410, 2019.

Martins J.P.R., Rodrigues L.C.A., Silva T.S. et al.: Morphophysiological responses of Aechmea blanchetiana (Bromeliaceae) to excess copper during in vitro culture. Plant Biosyst. 155: 447-456, 2021.

Martins J.P.R., SchimildtE.R., Alexandre R.S. et al.: Chlorophyll a fluorescence and growth of Neoregelia concentrica (Bromeliaceae) during acclimatization in response to light levels. - In Vitro Cell. Dev.-Pl. 51: 471-481, 2015.

Martins J.P.R., Vasconcelos L.L., Braga P.C.S. et al.: Morphophysiological responses, bioaccumulation and tolerance of Alternanthera tenella Colla (Amaranthaceae) to excess copper under in vitro conditions. - Plant Cell Tiss. Org. Cult. 143: 303-318, 2020.

Mazaheri-Tirani M., Dayani S.: In vitro effect of zinc oxide nanoparticles on Nicotiana tabacum callus compared to $\mathrm{ZnO}$ micro particles and zinc sulfate $\left(\mathrm{ZnSO}_{4}\right)$. - Plant Cell Tiss. 
Org. Cult. 140: 279-289, 2020

Men C., Liu R., Xu F. et al.: Pollution characteristics, risk assessment, and source apportionment of heavy metals in road dust in Beijing, China. - Sci. Total Environ. 612: 138-147, 2018.

Meng L.L., Song J.F., Wen J. et al.: Effects of drought stress on fluorescence characteristics of photosystem II in leaves of Plectranthus scutellarioides. - Photosynthetica 54: 414-421, 2016.

Murashige T., Skoog F.: A revised medium for rapid growth and bioassays with tobacco tissue cultures. - Physiol. Plantarum 15: 473-497, 1962.

Pastuszak J., Kopeć P., Płażek A. et al.: Cadmium accumulation in the grain of durum wheat is associated with salinity resistance degree. - Plant Soil Environ. 66: 257-263, 2020.

Paunov M., Koleva L., Vassilev A. et al.: Effects of different metals on photosynthesis: cadmium and zinc affect chlorophyll fluorescence in durum wheat. - Int. J. Mol. Sci. 19: 787, 2018.

Pereira M.P., Rodrigues L.C.A., Corrêa F.F. et al.: Cadmium tolerance in Schinus molle trees is modulated by enhanced leaf anatomy and photosynthesis. - Trees 30: 807-814, 2016.

Pérez-Romero J.A., Redondo-Gómez S., Mateos-Naranjo E.: Growth and photosynthetic limitation analysis of the Cdaccumulator Salicornia ramossisima under excessive cadmium concentrations and optimum salinity conditions. Plant Physiol. Bioch. 109: 103-113, 2016.

Pires-Lira M.F., Castro E.M., Lira J.M.S. et al.: Potential of Panicum aquanticum Poir. (Poaceae) for the phytoremediation of aquatic environments contaminated by lead. - Ecotox. Environ. Safe. 193: 110336, 2020.

Pontes M.S., Graciano D.E., Antunes D.R. et al.: In vitro and in vivo impact assessment of eco-designed $\mathrm{CuO}$ nanoparticles on non-target aquatic photoautotrophic organisms. J. Hazard. Mater. 396: 122484, 2020.

Rajput V.D., Minkina T., Fedorenko A. et al.: Effects of zinc oxide nanoparticles on physiological and anatomical indices in spring barley tissues. - Nanomaterials 11: 1722, 2021.

Rastogi A., Zivcak M., Tripathi D.K. et al.: Phytotoxic effect of silver nanoparticles in Triticum aestivum: Improper regulation of photosystem I activity as the reason for oxidative damage in the chloroplast. - Photosynthetica 57: 209-216, 2019.

Rodrigues L.C.A., Martins J.P.R., Almeida Júnior O. et al.: Tolerance and potential for bioaccumulation of Alternanthera tenella Colla to cadmium under in vitro conditions. - Plant Cell Tiss. Org. Cult. 130: 507-519, 2017.

Samiei L., Pahnehkolayi M.D., Karimian Z., Nabati J.: Morphophysiological responses of halophyte Climacoptera crassa to salinity and heavy metal stresses in in vitro condition. S. Afr. J. Bot. 131: 468-474, 2020.

Shahid A., Ahmad N., Anis M. et al.: Morphogenic responses of Rauvolfia tetraphylla L. cultures to $\mathrm{Cu}, \mathrm{Zn}$ and $\mathrm{Cd}$ ions. Rend. Lincei Sci. Fis. Nat. 27: 369-374, 2016.

Singh S., Singh A., Srivastava P.K., Prasad S.M.: Cadmium toxicity and its amelioration by kinetin in tomato seedlings vis-à-vis ascorbate-glutathione cycle. - J. Photoch. Photobio. B 178: 76-84, 2018.

Somavilla L.M., Simão D.G., Tiecher T.L. et al:: Structural changes in roots of peach rootstock cultivars grown in soil with high zinc content. - Sci. Hortic.-Amsterdam 237: 1-10, 2018.

Souza A.F.C., Martins J.P.R., Gontijo A.B.P.L., Falqueto A.R.: Selenium improves the transport dynamics and energy conservation of the photosynthetic apparatus of in vitro grown Billbergia zebrina (Bromeliaceae). - Photosynthetica 57: 931-941, 2019.
Stirbet A., Lazár D., Kromdijk J., Govindjee: Chlorophyll $a$ fluorescence induction: Can just a one- second measurement be used to quantify abiotic stress responses? - Photosynthetica 56: 86-104, 2018.

Strasser R.J., Tsimilli-Michael M., Srivastava A.: Analysis of the chlorophyll $a$ fluorescence transient. - In: Papageorgiou G.C., Govindjee (ed.): Chlorophyll $a$ Fluorescence: A Signature of Photosynthesis. Advances in Photosynthesis and Respiration. Pp. 321-362. Springer, Dordrecht 2004.

Sturikova H., Krystofova O., Huska D., Adam V.: Zinc, zinc nanoparticles and plants. - J. Hazard. Mater. 349: 101-110, 2018.

Verma S.K., Sahin G., Das A.K., Gurel E.: In vitro plant regeneration of Ocimum basilicum L. is accelerated by zinc sulfate. - In Vitro Cell. Dev.-Pl. 52: 20-27, 2016.

Wafee C., Khan A.S., Siddiqi M.R.: Phytoremediation potential of Catharanthus roseus L. and effects of lead $(\mathrm{Pb})$ toxicity on its morpho-anatomical features. - Pak. J. Bot. 50: 1323-1326, 2018.

Wang Q., Zhang Q., Wu Y., Wang X.C.: Physicochemical conditions and properties of particles in urban runoff and rivers: implications for runoff pollution. - Chemosphere 173: 318-325, 2017a.

Wang Y.W., Xu C., Lv C.F. et al.: Chlorophyll a fluorescence analysis of high-yield rice (Oryza sativa L.) LYPJ during leaf senescence. - Photosynthetica 54: 422-429, 2016.

Wang Y.W., Xu C., Wu M., Chen G.X.: Characterization of photosynthetic performance during reproductive stage in high-yield hybrid rice LYPJ exposed to drought stress probed by chlorophyll $a$ fluorescence transient. - Plant Growth Regul. 81: 489-499, $2017 \mathrm{~b}$.

Wilkins D.A.: A technique for the measurement of lead tolerance in plants. - Nature 180: 37-38, 1957.

Wiszniewska A., Hanus-Fajerska E., Muszyńska E., Smoleń S.: Comparative assessment of response to cadmium in heavy metal-tolerant shrubs cultured in vitro. - Water Air Soil Poll. 228: 304, 2017.

Wu C., Dun Y., Zhang Z. et al.: Foliar application of selenium and zinc to alleviate wheat (Triticum aestivum L.) cadmium toxicity and uptake from cadmium-contaminated soil. Ecotox. Environ. Safe. 190: 110091, 2020.

$\mathrm{Xu}$ P., Chen Y., He S. et al.: A follow-up study on the characterization and health risk assessment of heavy metals in ambient air particles emitted from a municipal waste incinerator in Zhejiang, China. - Chemosphere 246: 125777, 2020.

Yusuf M.A., Kumar D., Rajwanshi R. et al.: Overexpression of $\gamma$-tocopherol methyl transferase gene in transgenic Brassica juncea plants alleviates abiotic stress: physiological and chlorophyll fluorescence measurements. - BBA-Bioenergetics 1797: 1428-1438, 2010.

Zhang H., Xu N., Wu X. et al.: Effects of four types of sodium salt stress on plant growth and photosynthetic apparatus in sorghum leaves. - J. Plant Interact. 13: 506-513, 2018.

Zhang H.H., Xu N., Li X., Gu S.Y.: Over expression of 2-Cys Prx increased salt tolerance of photosystem II (PSII) in tobacco. PeerJ Preprints 4: e2500v1, 2016.

Zhang L., Su F., Zhang C. et al.: Changes of photosynthetic behaviors and photoprotection during cell transformation and astaxanthin accumulation in Haematococcus pluvialis grown outdoors in tubular photobioreactors. - Int. J. Mol. Sci. 18: 33, 2017.

Zhuo Y., Qiu S., Amombo E. et al.: Nitric oxide alleviates cadmium toxicity in tall fescue photosystem II on the electron donor side. - Environ. Exp. Bot. 137: 110-118, 2017.

(C) The authors. This is an open access article distributed under the terms of the Creative Commons BY-NC-ND Licence. 